Document downloaded from:

http://hdl.handle.net/10251/58752

This paper must be cited as:

Garrido-Villén, N.; Berné Valero, JL.; Antón Merino, A.; Anquela Julián, AB. (2014). Jurisdictional boundaries in Spain, survey and marking of boundaries in Teruel (Spain). Survey Review. 46(336):205-212. doi:10.1179/1752270613Y.0000000071.

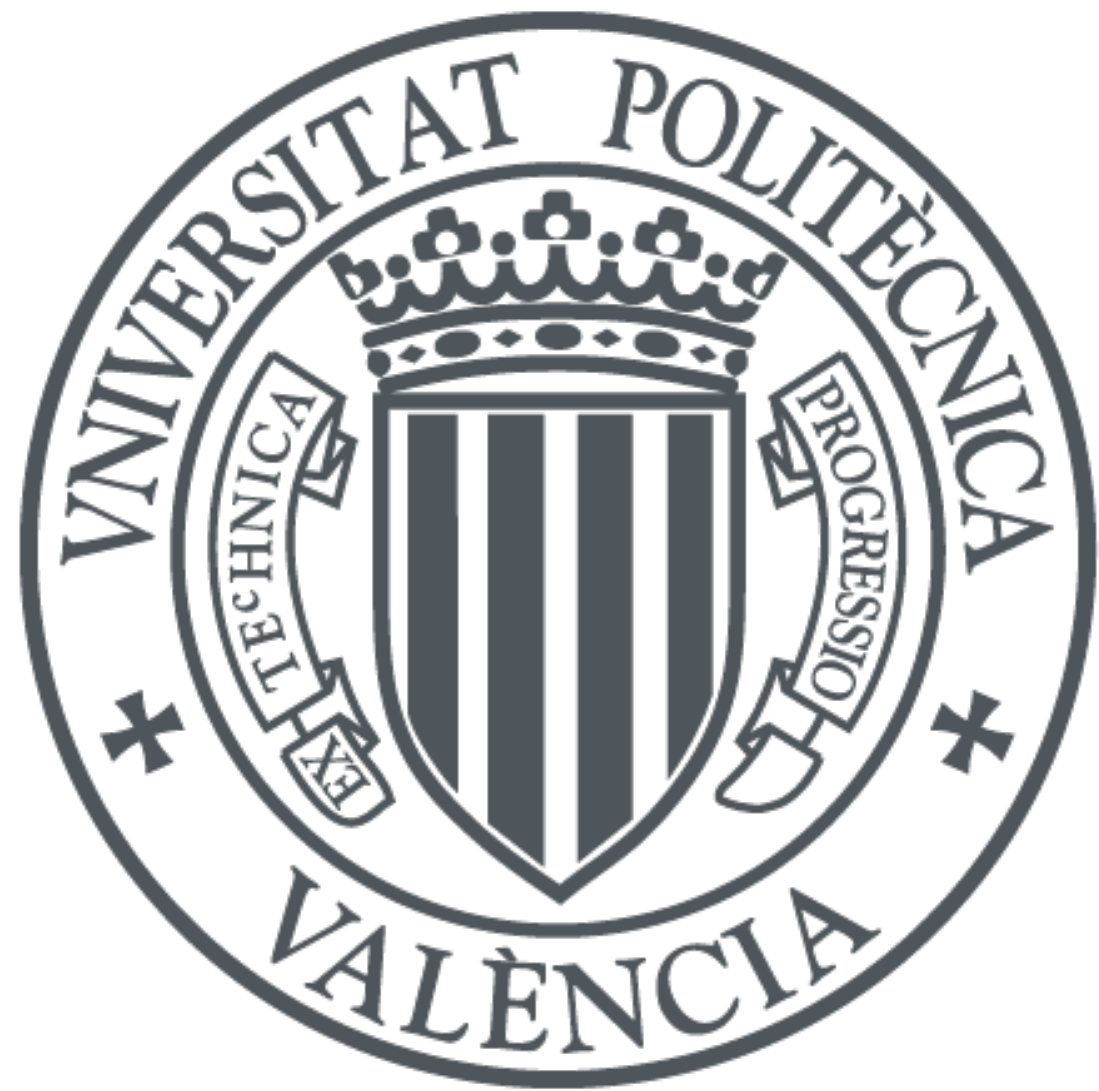

The final publication is available at

http://dx.doi.org/10.1179/1752270613Y.0000000071

Copyright Maney Publishing

Additional Information 


\title{
JURISDICTIONAL BOUNDARIES IN SPAIN
}

\section{SURVEY AND MARKING OF BOUNDARIES IN TERUEL (SPAIN)}

\author{
N. Garrido-Villén, J. L. Berné-Valero, A. Antón-Merino, A. Anquela Julián \\ Department of Cartographic, Geodetic and Photogrammetric Engineering \\ Universitat Politècnica de València, Spain
}

\begin{abstract}
In the 1890's and early 1900s, the National Geographic Institute (IGN) of Spain carried out geodetic studies required to georeference the boundaries of every single municipality in Spain, survey the boundaries and mark them out. The field notes for these studies still exist and can still be referenced today.

Nowadays, most of the landmarks that were located in these studies have disappeared; replacing these monuments could be of great interest to the local government, both administratively and economically. The indeterminacy or change of municipal boundaries can lead to tax collection and even supply problems.

This paper studies the accuracy of those studies. Furthermore, a technical method for locating the lost monuments is shown; this method could also be used to map the monuments in a precise and reliable way. In this way, the problem of replacing boundaries is subsequently analysed.
\end{abstract}

KEY WORDS: Boundary demarcation. Boundary survey. Topography. Geodesy. Layout.

\section{INTRODUCTION}

Since the time of the first civilizations, the idea of territory as an area of a particular jurisdiction has existed; this jurisdiction could be imperial (roman territorium) feudal (castles), or ecclesiastical (parishes), etc. Hence, territory could be identified as the physical framework in which human activity takes place and where political power is carried out [2]. A municipal territory is the space where councils are competent, and this territory could be called a municipal district.

The first definition found in most dictionaries for the term territory is something like: "A piece of land property of a nation, state, region, province, etc." Therefore, the concept of territory involves the existence of boundaries; and for this territory to be identified, such boundaries must be well defined. This definition must consist in permanent physical elements, elements which are acknowledged by every party involved. In the case under study, every local administration affected by the boundary must recognize those physical elements.

It is known that Egyptians and Romans surveyed and demarcated private plots. The former did so because when the Nile river rose, it caused boundary marks to disappear year after year, whereas the latter's purpose was to share out the conquered lands among settlers and graduate soldiers. The Romans drew out centuria on fields with the help of landmarks where the boundaries crossed called limes.

Historically those with politic power have demarcated boundaries in many different ways; the most popular consisted in placing some kind of marks on the field. Consequently, to identify a jurisdictional perimeter, these marks simply had to be joined with an invisible line. The marks could be stones, marks in rocks, pillars, etc. One of the main characteristics of these landmarks is that, in the cases under study in this paper, they were usually placed in a prominent place and were used taking into consideration that they were considered to be permanent. 
Due to the limited accuracy of the works carried out to demarcate the municipal boundaries in Spain, there is a lack of agreement as to the landmarks in the ground, and if they still remain, as well as the mapping of Local Land Register. This situation leads to many problems, mainly economic, because of possible tax collection efforts of the municipalities, all of which are enlarged by the current economic crisis.

\section{JURISDICTIONAL BOUNDARY DEMARCATIONS IN SPAIN}

Around one century ago, IGN. carried out the geodetic works required to define and map the boundaries of every single municipality in Spain. Of course, it was the first time that every municipal boundary was surveyed and authenticated. The works encompassed: an agreement by every party involved as to the location of monuments and boundary lines, the topographic surveying of municipal perimeters and the drawing of the boundaries in a 1:25,000 scale cartography [7].

In general, the topographic works consisted in joining the monuments to identify the boundary line. For this purpose, a polygonal line was made surveyed with a tachymetric compass and stadia. Fig.1 show the original topographic works carried out by IGN.

Those works marked the end of a long process that had started with the first modern definition of a municipality in Spain; a definition set forth in the 1812 Constitution called the Constitution of Cádiz.

Boundary lines can be classified as natural or artificial; and there are three types of artificial boundaries: astronomical boundaries (following parallels and meridians), mathematical boundaries (connecting two certain points) and reference boundaries (referenced to one or several points [3]. These are the boundaries be studied in this paper.

Demarcating boundaries between two municipalities is an administrative and legal process; this process involves setting up the boundary line between municipalities and having them agreed by every municipality involved, following which the results of the process are recorded in a document called boundary demarcation minutes.

The aforementioned process is the same now as when the first such works were carried out:

- Ratification of the boundary lines drawn by a committee from every municipality involved. These committees consist of: the mayor, three city councillors, the secretary, a survey expert, two elderly people who know the field and security forces. Every municipality sends the related minutes to the relevant autonomous regional government. The autonomous regional government then appoints an engineer who is responsible for carrying out the boundary surveys and sends a copy of the boundary demarcation minutes to the IGN. If there is an agreement regarding the boundary line, the municipalities draft a joint document to inform the state government. Finally the State Government includes the boundary line in a special land register. If there is no agreement, the municipalities involved sign a separate document.

- Topographic works to mark out the boundary line. 


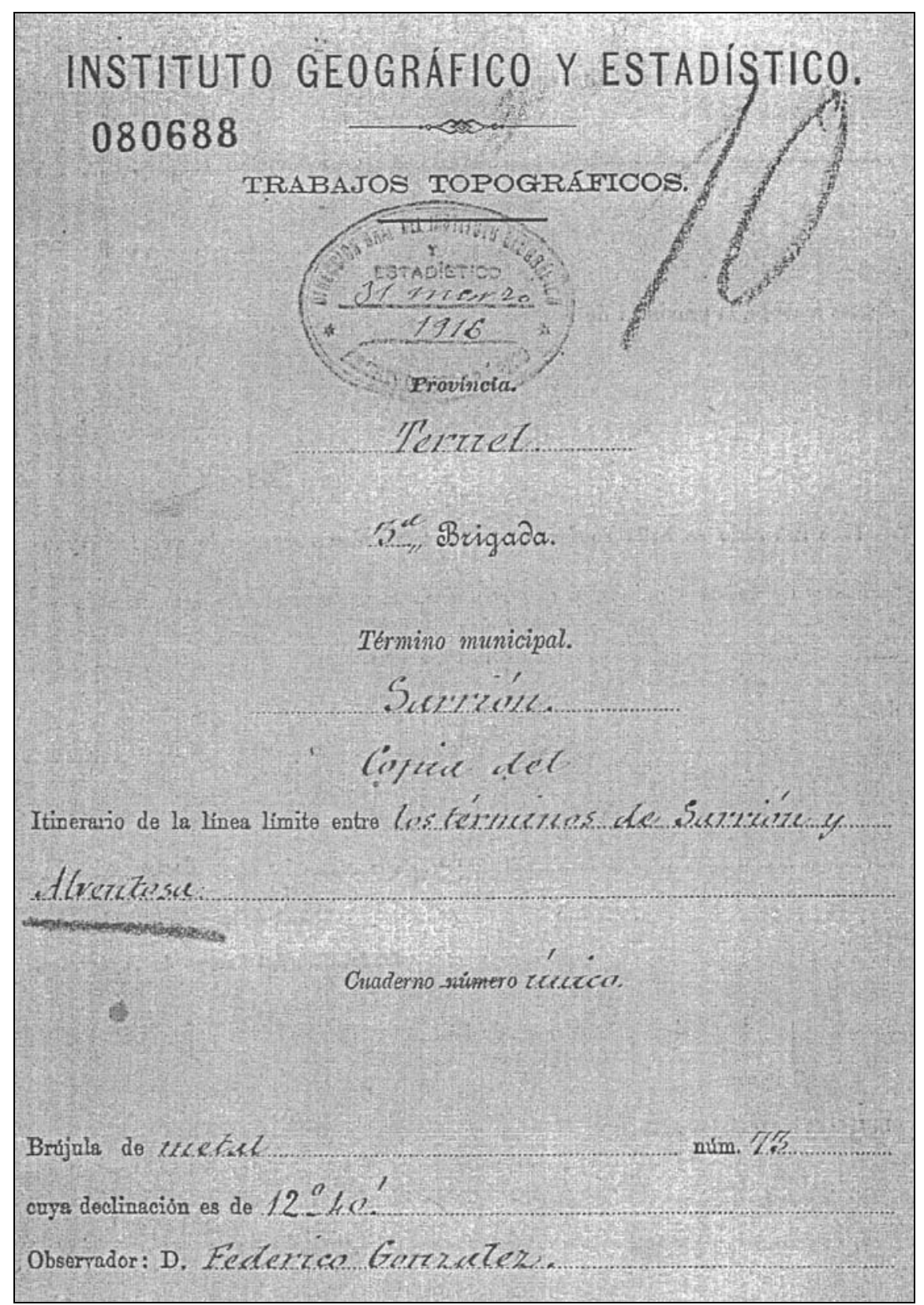

Figure 1. Topographic works to georeference the boundary line between Albentosa and Sarrión - Teruel (Spain). IGN

\section{Technical methodology used in boundary demarcation}

Topographic works to georeference the boundary lines were carried out to be able to lay out the lost monuments, in the case that they had disappeared, although the methodology and the instruments used did not guarantee the required accuracy.

In most cases the instrument used was a tachymetric compass, as shown in Fig. 2. This instrument was used to measure direction and angles with the help of a compass orientation referenced to magnetic north. Consequently, measured angles are called magnetic bearings and it is necessary to know the magnetic declination at a specific time in a specific place. The advantage of this instrument is that it is very easy to use, but a tachymetric compass offers very poor precision, owing to the periodic variation of terrestrial magnetism and isolated magnetic anomalies of the terrain. 


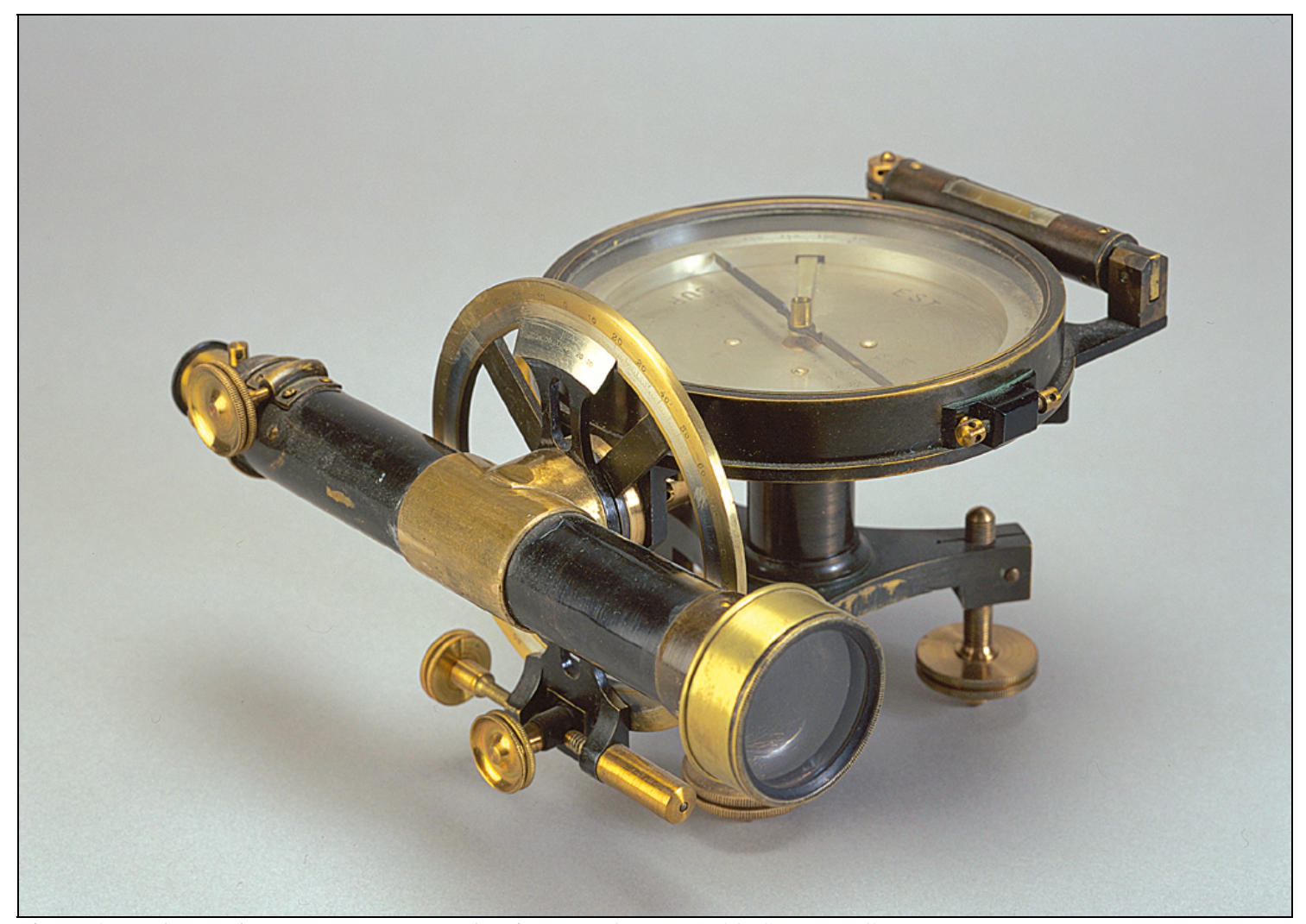

Figure 2. Tachymetric compass. Laguna de Rins Brand. Year 1980. Source: IGN

www.ign.es/ign/home/cartografia/museovirtual/instrumentos.jsp

Measurements made using the compass and stadia were recorded in field tablets and included the following: bearings, vertical angles, stadia rod measurements, magnetic declination at the time of observation, details about the methodology used, etc. Therefore, the boundary line was geometrically defined in field tablets according to boundary demarcation minutes although the itineraries described in field tablets were analytically free and could not be matched to points with known and precise coordinates. Therefore, using solely this data it was impossible to place the boundary line in an absolute way, limiting the possibility of future demarcations to a great extent, especially considering that a large number of monuments have disappeared.

An important reason why boundary lines are not exactly defined, even though it is now technically possible; is that in most parts of the country, the cost of the survey exceeds the value of the land to be surveyed [4]. However, in cases when the value of the land is important, the situation could be difficult.

\section{SPANISH CADASTRE}

Article 1 of the Spanish law 48/2002, of December 23rd, on the Real Estate Cadastre [6] says: "the Real Estate Cadastre is an administrative register reporting to the Treasury Department in which rural and urban real estate and property with special characteristics is described in the form provided in this law"

Hence, the Spanish Cadastre could be defined as a descriptive census of properties; which contains records on every Real-estate property located in Spain [1].

Royal Decree $585 / 1989$, of May $26^{\text {th }}$, enacting Law $7 / 1986$, of January $24^{\text {th }}$, on cadastral cartography states the following:

- Article 2. A cadastral cartography is a graphic document defining among other characteristics considered to be relevant, the shape, dimensions and situation of the different properties that make up the national territory, whatever their use 
may be, which all together composes the graphic medium of the Cadastre.”

Additionally, as provided in Royal Decree 2949/1979, of December $29^{\text {th }}$, on the IGN competences in relation to Real-estate Topographic National Map[7]:

"Current cartographic requirements give the Real-estate Cadastre the nature of national Real-estate Topographic map, which may be based on a uniform reference system that may be only defined by the National Geodetic Network. This map will serve a double purpose, being used as geographic bases to make up the Cadastral National Data Bank and for undertaking urban planning studies.

(...)

Article 1.

1. The Real-estate Topographic National Map drawn by the National Geographic Institute is the only map valid for the purpose of Cadastral geometric bases.

2. This map shall be the geometrical base of the Cadastral Data National Bank.

Article 2.

For the purpose of the required homogeneity and technical precision, in the land survey as well as the conservation and layout, the Map shall be based on the National Geodetic Network..."

In conclusion, from the Engineer's point of view, the Cadastre is the only complete and continuous cartography of Spain in which property boundaries are included.

\section{SPANISH NATIONAL GEODETIC NETWORK}

As mentioned above, the National Geodetic Network is the basis for the Cadastre and for the rest of the mapping services of the country. Creating, sustaining and upgrading the network and increasing the number of geodetic network points to allow mapping activities on different scales is of great significance [5]. All these works are carried out by the IGN and nowadays there is a Conventional National Geodetic Network that has 11,000 vertexes in European Datum 1950 (ED-50), and another Spatial Methodology National Geodetic Network with 1,200 stations in the European Terrestrial Reference System 1989 (ETRS89) [8].

\section{STUDY ON THE PRECISION OF BOUNDARY LINES: A PRACTICAL CASE}

In this paper, a small section of the Boundary line between two village municipalities located in the province of Teruel in Spain called Albentosa and Sarrión were studied. The boundary line is $1.5 \mathrm{~km}$ long and is marked by three monuments.

The boundary demarcation minute was drafted on July $10^{\text {th }} 1900$ and the topographic works to georeference this boundary lines were carried out on September $19^{\text {th }} 1900$. As previously mentioned, the topographic works were carried out with a metallic compass and the magnetic declination for these works was $12^{\circ} 40^{\prime}$. Both village councils indicated where the boundary line was placed and an itinerary was carried out.

Fig. 3 shows a field tablet were the survey notes can be seen: bearings, stadia data, vertical angles and horizontal distances.

A real-estate developer was developing a golf course and a housing estate in the mentioned area. In order to obtain the required permits they needed to have the rural property and its real area registered in the Property Register, and therefore it was 
necessary to check the boundary line. Hence, on June $23^{\text {rd }} 2009$ the works were carried out.

The Aragón Government's Environmental Provincial Service under the autonomous regional government, asked the real-estate developer to have the minutes and field tablets studied and checked. The cadastral cartography mentioned in the introduction was also studied, given that the mentioned boundary line was drawn in that cadastral cartography.

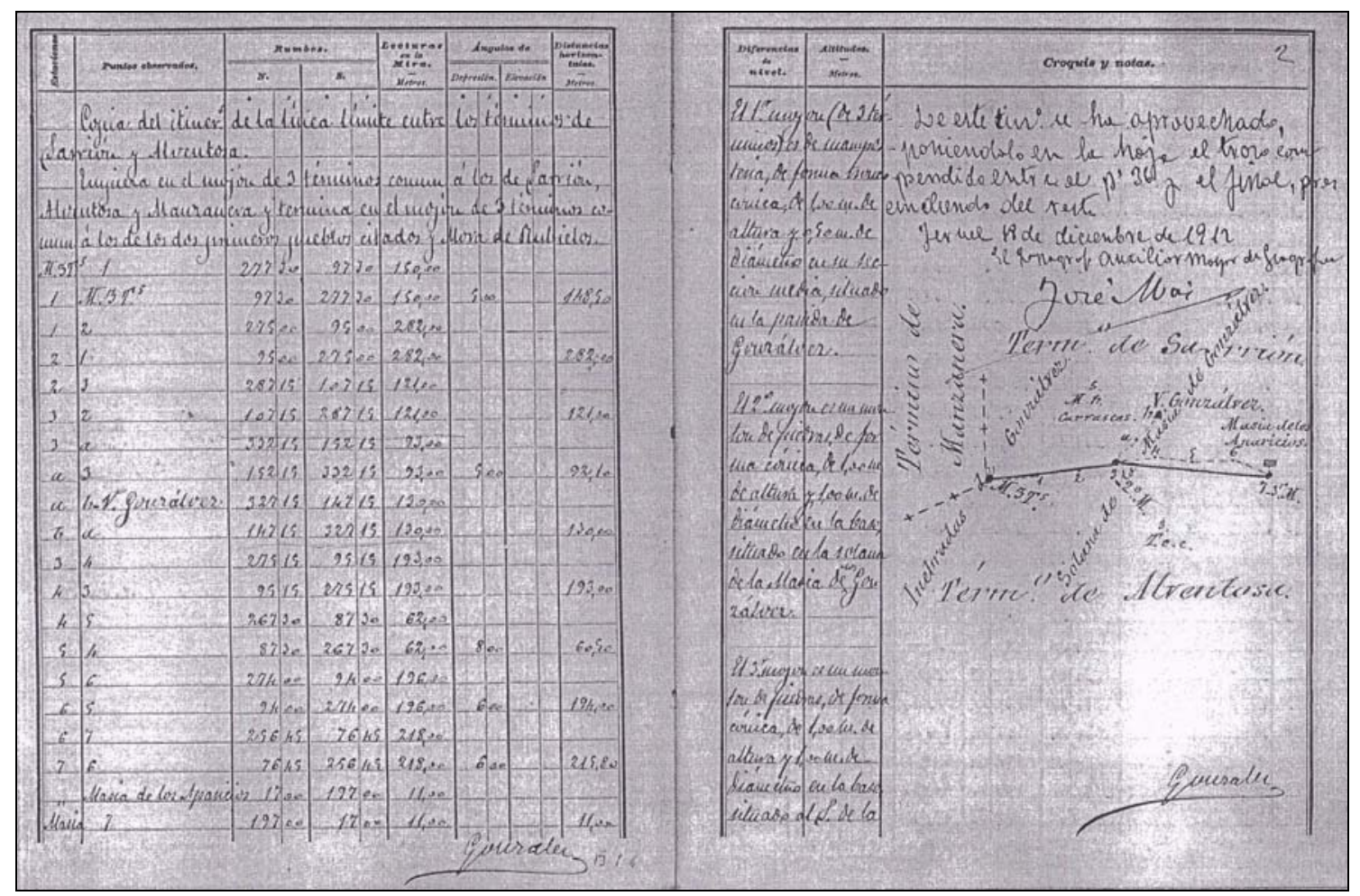

Figure 3. Field tablet indicating the survey notes for the boundary line under study. Source IGN

Three monuments are used to join together the boundary line, so the geographical descriptions of those monuments were studied. Subsequently, the land was visited in order to attempt to find those monuments. However, just one of them was found to be in good condition, another one could be deduced and the last one couldn't be found. Monuments were built by piles of stones. Elderly people, who knew the land, explained that those stones were used during the Civil War to build defensive forts.

The next step consisted in precisely georeferencing the monuments; in other words, introducing the monuments cartographic coordinates in an international geodetic reference framework.

The European Datum 1950 (ED-50) datum and Universal Transverse Mercator (UTM) coordinate system were used given that the datum and coordinate system are now used by the Cadastre in Spain.

Geodetic dual frequency Global Navigation Satellite System (GNSS) equipment was used to carry out the works. Due to the RTK technique competes well with the traditional survey methods in term of accuracy except in obstructed areas [9], and this was not the case.

Data were recorded in the nearest four geodetic vertexes using static methodology; the observation time was 30 minutes in each vertex and data were registered every 5 seconds. 
A new reference point was placed in the mentioned area to be used in future layouts and surveys. Furthermore, the coordinates of this new point were calculated in the mentioned system.

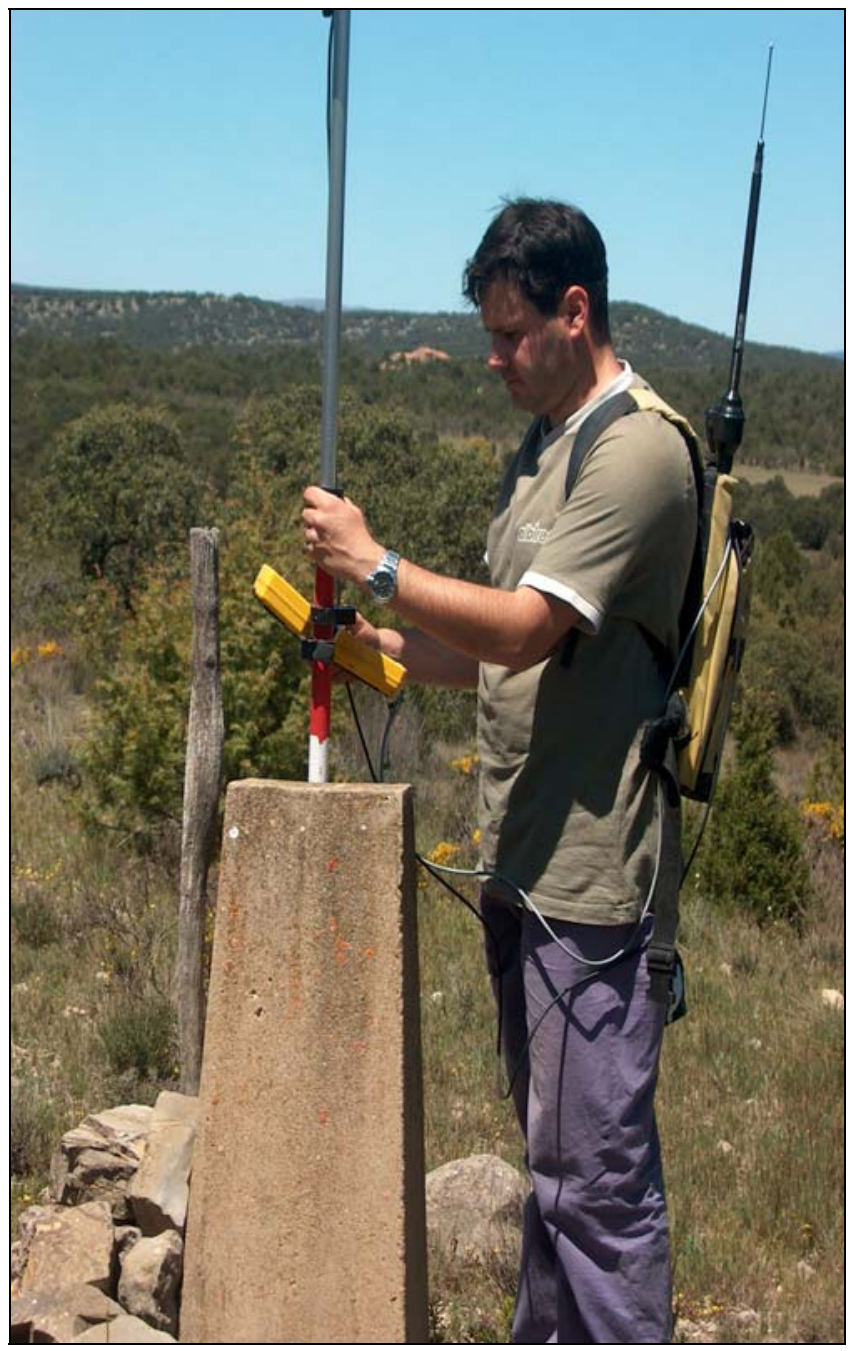

Figure 4 . Georeferencing the monument $\mathrm{n}^{\circ} 1$ by GNSS metholology

This new point was used to georeference the existing monuments by means of GNSS-RTK (Real Time Kinematic) surveys, as shown in Fig.4.

The monument which had disappeared was the one located between the existing ones. Topographic data from IGN field tablets were used to calculate the missing monument coordinates from the existing ones; these data included bearings and horizontal distances. Coordinates were calculated in two ways: from the first monument forwards and from the third monument backwards (in the same direction took by IGN). Both results gave a 7.8 meters difference, allowing the average coordinates to be calculated.

Using the coordinates obtained, the lost monument's layout was determined, the disappeared monument was searched for at this point. At about $6 \mathrm{~m}$ from the pointed place, a pile of scattered stones of about 4 metres was found; although it was quite low, and it could be easily found because there were the only big stones in that area, which is evidenced in Fig.5.

It was near the layout point and there were no big stones nearby. Therefore it was easy to deduce that this was the monument built 109 years ago. Once identified, its 
coordinates were taken to complete the boundary line, now referenced in a geodetic system in a precise and reliable way.

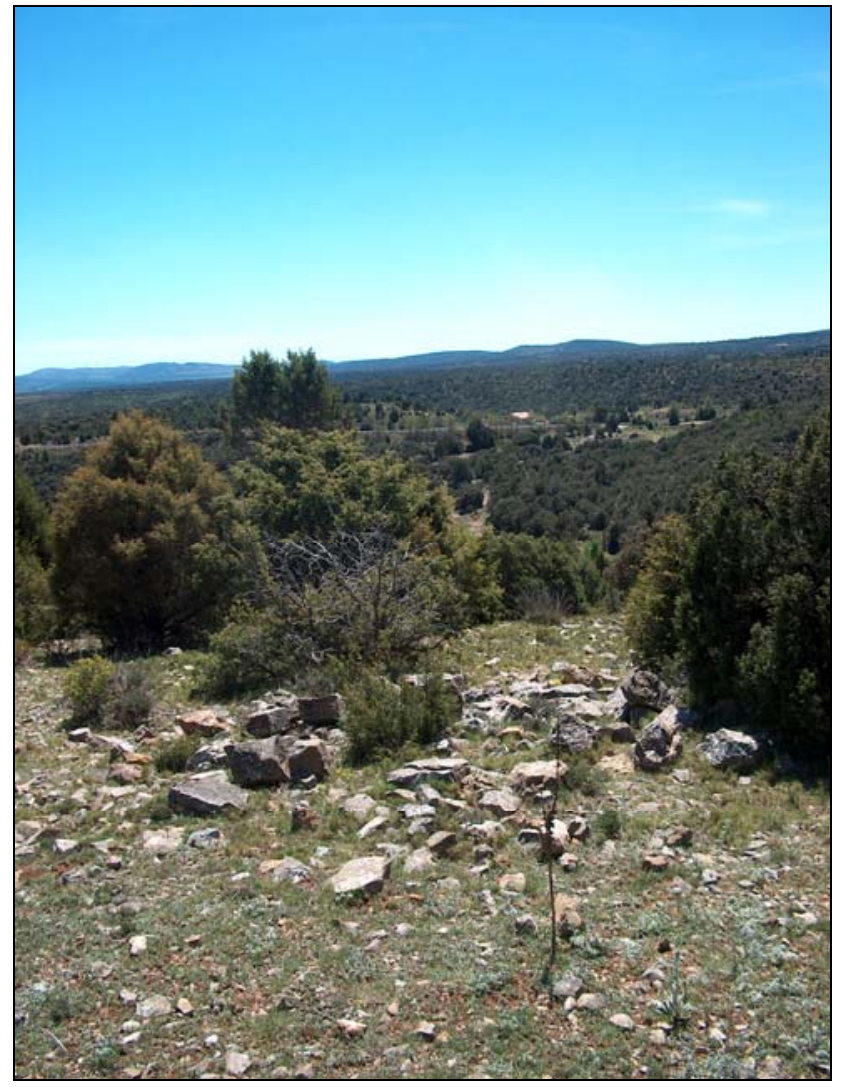

Fig. 5. Second Monument tumbledown remains, located about 6 meters from the calculated point with IGN field tablets data.

The last step consisted of comparing the boundary line cartography obtained with the boundary line included in the cadastral cartography. The error in relation to this boundary line was calculated to be more than 17 meters, which means that the boundary line in the studied area was moved 17 meters to the South along the $1.5 \mathrm{~km}$ of its length, all of which implied that solely in the studied area, there was an error of $25500 \mathrm{~m}^{2}$ in favour of the municipality of Albentosa. This area was erroneously assigned to Sarrion's municipality in the Cadastre.

This error is evidenced in Fig.6, which is an image taken from the official web page of the Spanish Cadastre. Looking carefully at the boundary line in blue with a plus and minus symbol, it can be observed there is not a single line but two lines defining the same boundary. That means that discrepancies even exist in the cartography of the same official agency. 


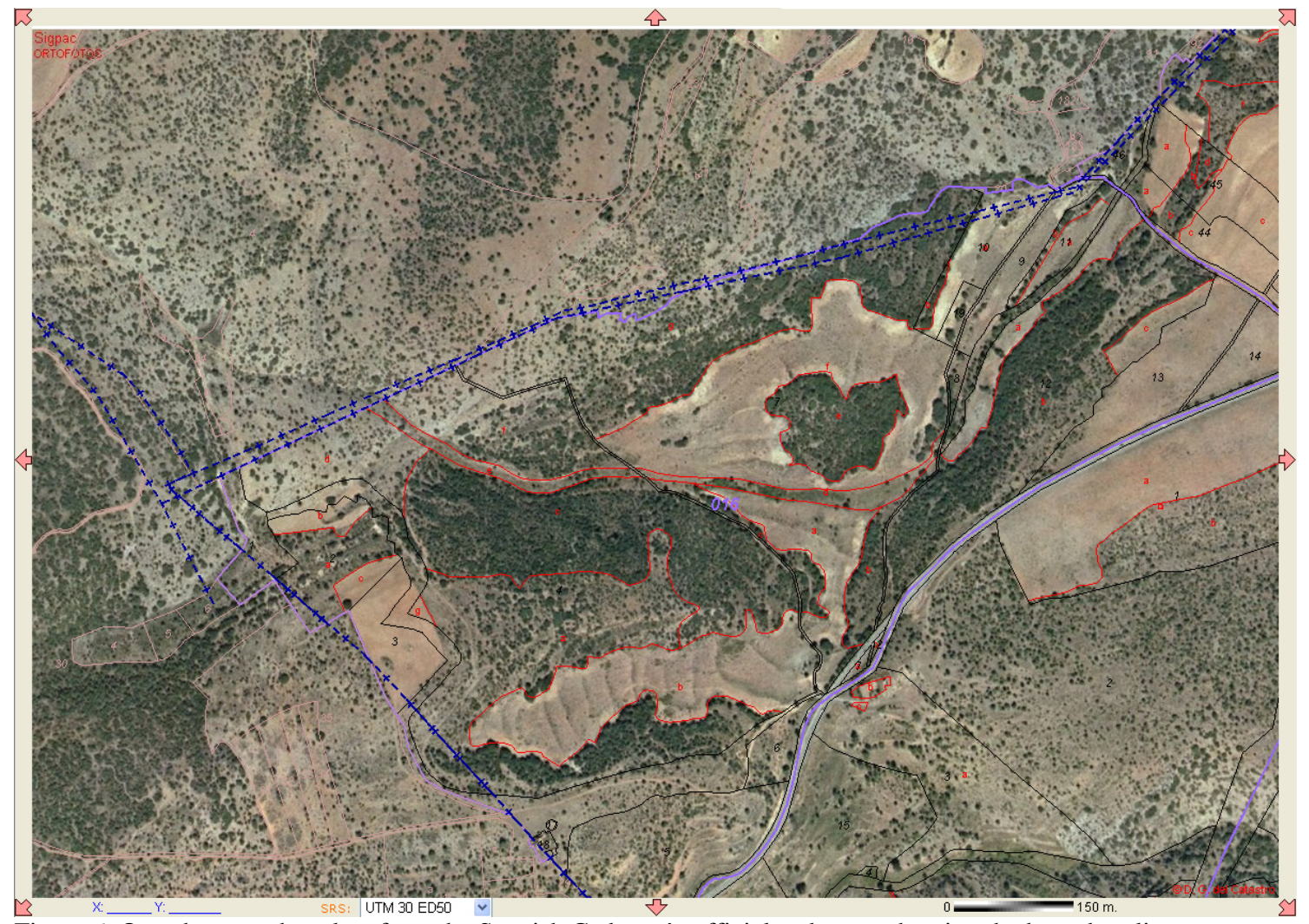

Figure 6. Ortophotography taken from the Spanish Cadastre's official web page showing the boundary line involved.

As previously mentioned, the main objective of the work was to have the rural property registered in the Land Register which was accomplished using the report drafted on the works described.

Concerning the detected discrepancy between the Cadastre and IGN cartography, the Albentosa municipality was contacted and stated that solving this problem is a very long process since several commissions must check the works, then visit the place at the same time and agree to the result; which could take years because nowadays there is no interest in the subject, being that is a rural land where there are not yet any buildings, and there are no funds to have this work carried out.

\section{PROBLEMS CAUSED BY THE INDETERMINACY OF MUNICIPAL BOUNDARIES}

In the example studied there was no conflict between local governments, but that's not always the case. The issue of jurisdictional boundaries involves numerous problems, and even more so given the current economic crisis.

The problems mentioned can be of a different nature, ranging from disputes over the use of public woodland to conflicts over the ownership of urban areas.

The most important problems can come from urban areas, because it is these areas that provide a greater amount of funds to municipalities in the form of taxes. Every property pays council tax, which is much greater if the property is urban. A municipality may request a review of the boundary if they suspect that certain buildings owned by another municipality that are in its municipal district. If so, the council that has the conflict zone will collect the assessment of the properties located there. In return, the municipality that "lost" these buildings can deny the supply of services such as water, electricity, etc., resulting in problems for citizens living in the area. 
Following are two of many examples of potential conflict resulting from the inaccurate positioning of municipal boundary lines.

Fig.7 and Fig.8 show the discrepancy between two municipal boundary lines, even shown by Spanish Cadastre. In this case, the boundary line (in blue) crosses an urban property, but there are no building structures.

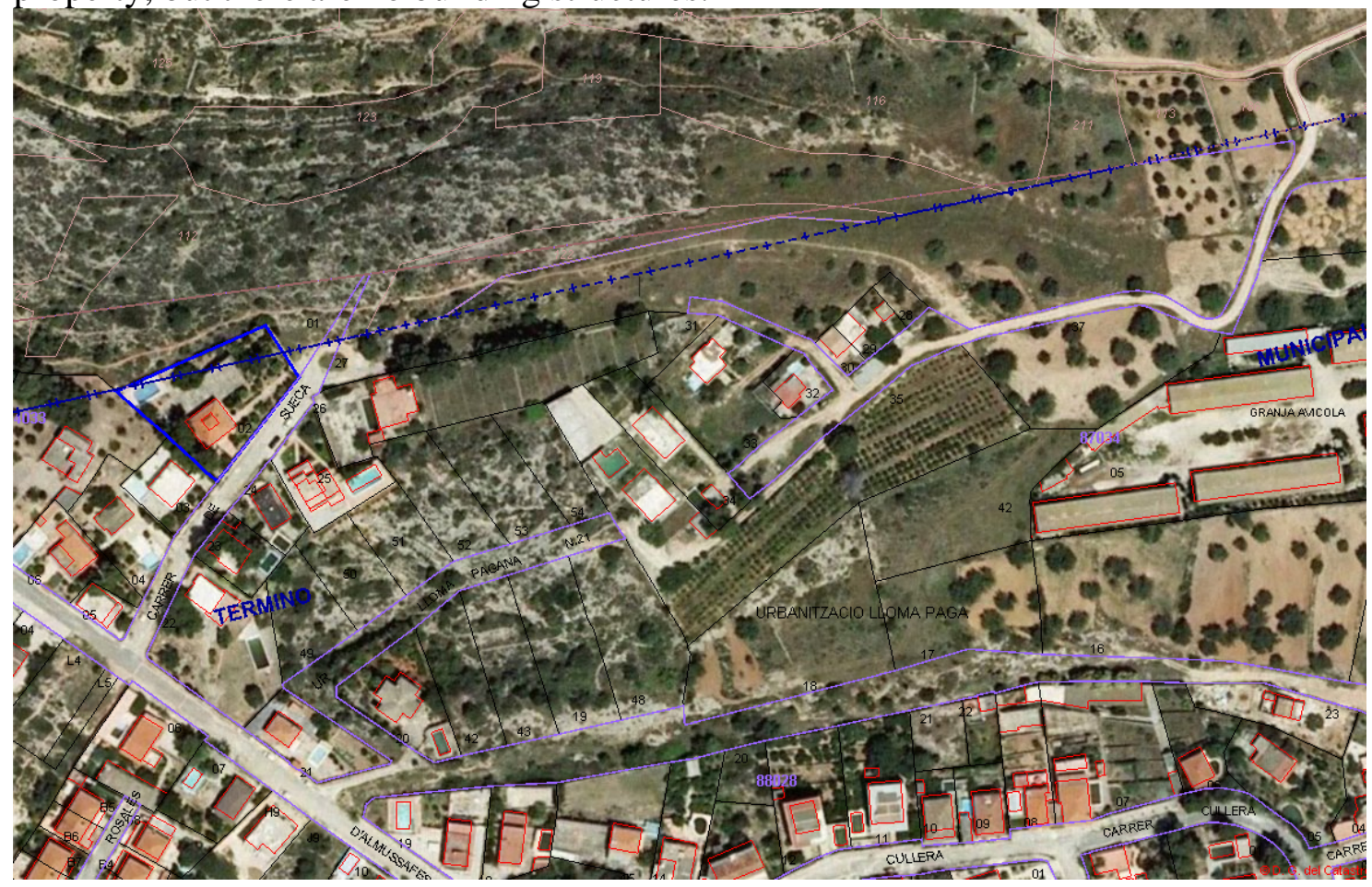

Figure 7. Ortophotography taken from the Spanish Cadastre's official web page showing a boundary line crossing an urban property in the town of Catadau (Valencia).

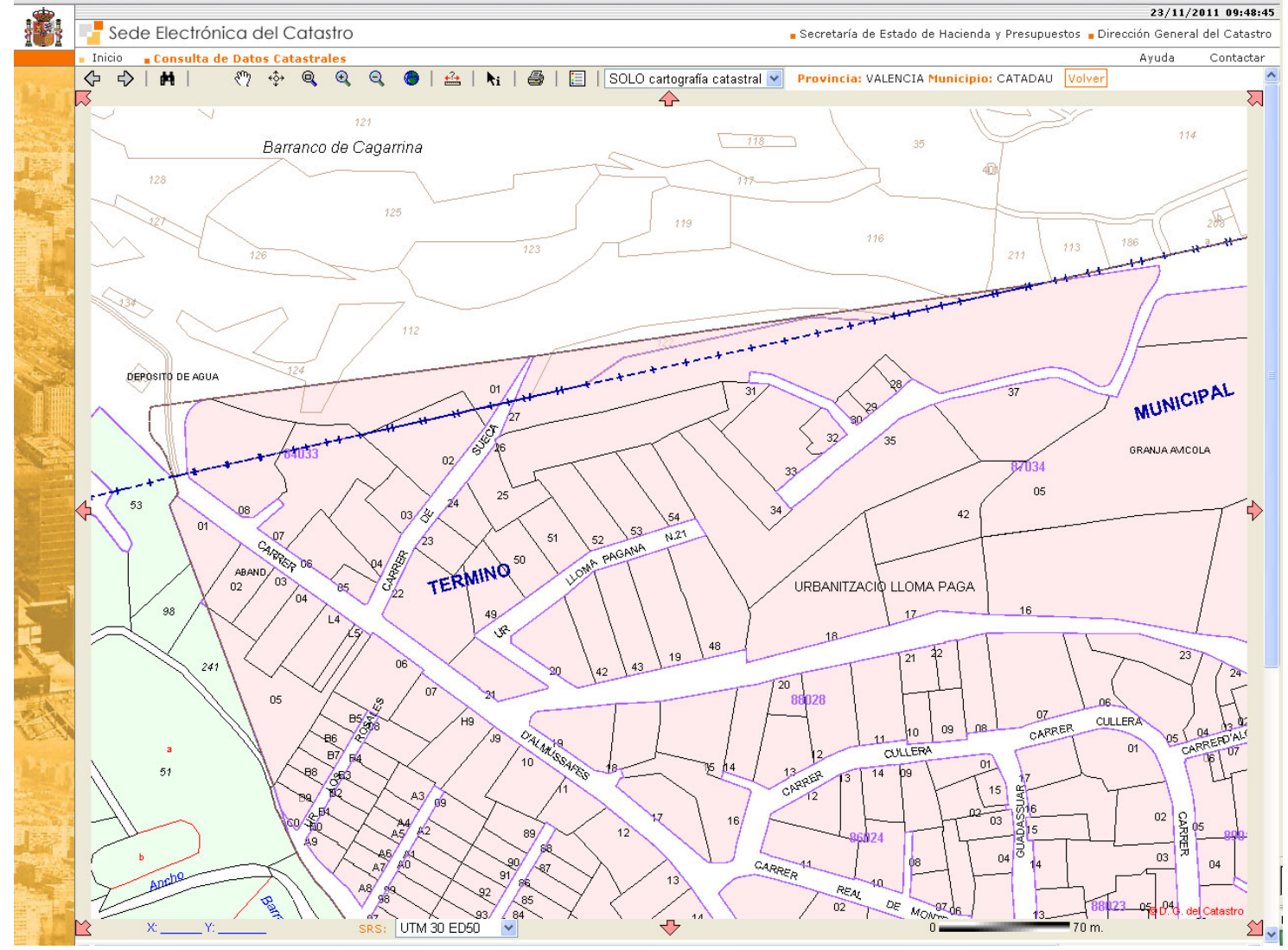

Figure 8. Cartography taken from the Spanish Cadastre’s official web page showing the same boundary line as Fig.7. 
Fig.9 and Fig.10 show the discrepancy between another two municipal boundary lines, also taken from Spanish Cadastre. This is a more difficult case, because the boundary line (in blue) crosses some urban property, and even some buildings.

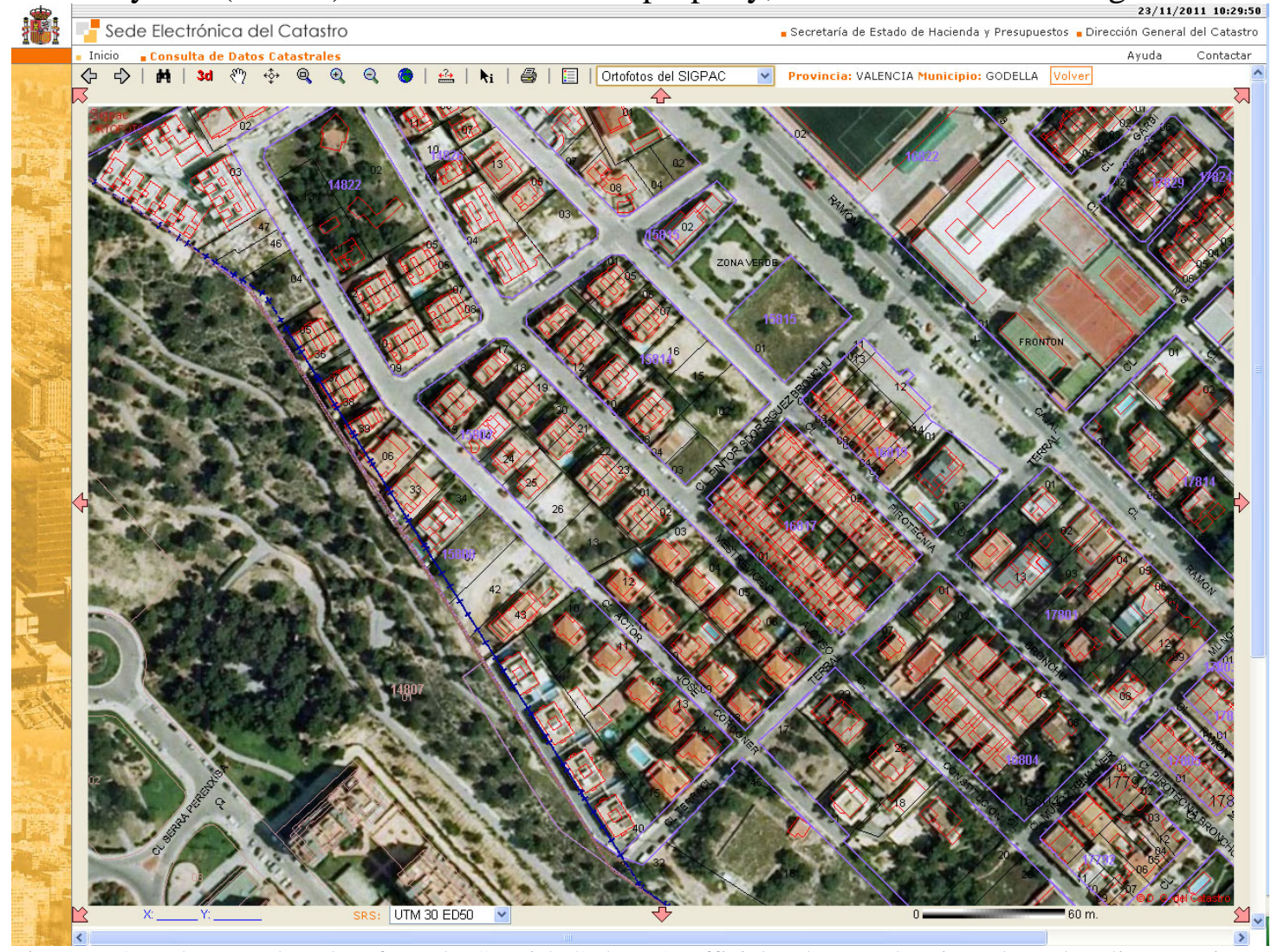

Figure 9. Ortophotography taken from the Spanish Cadastre’s official web page showing a boundary line crossing some urban properties in the town of Godella (Valencia).

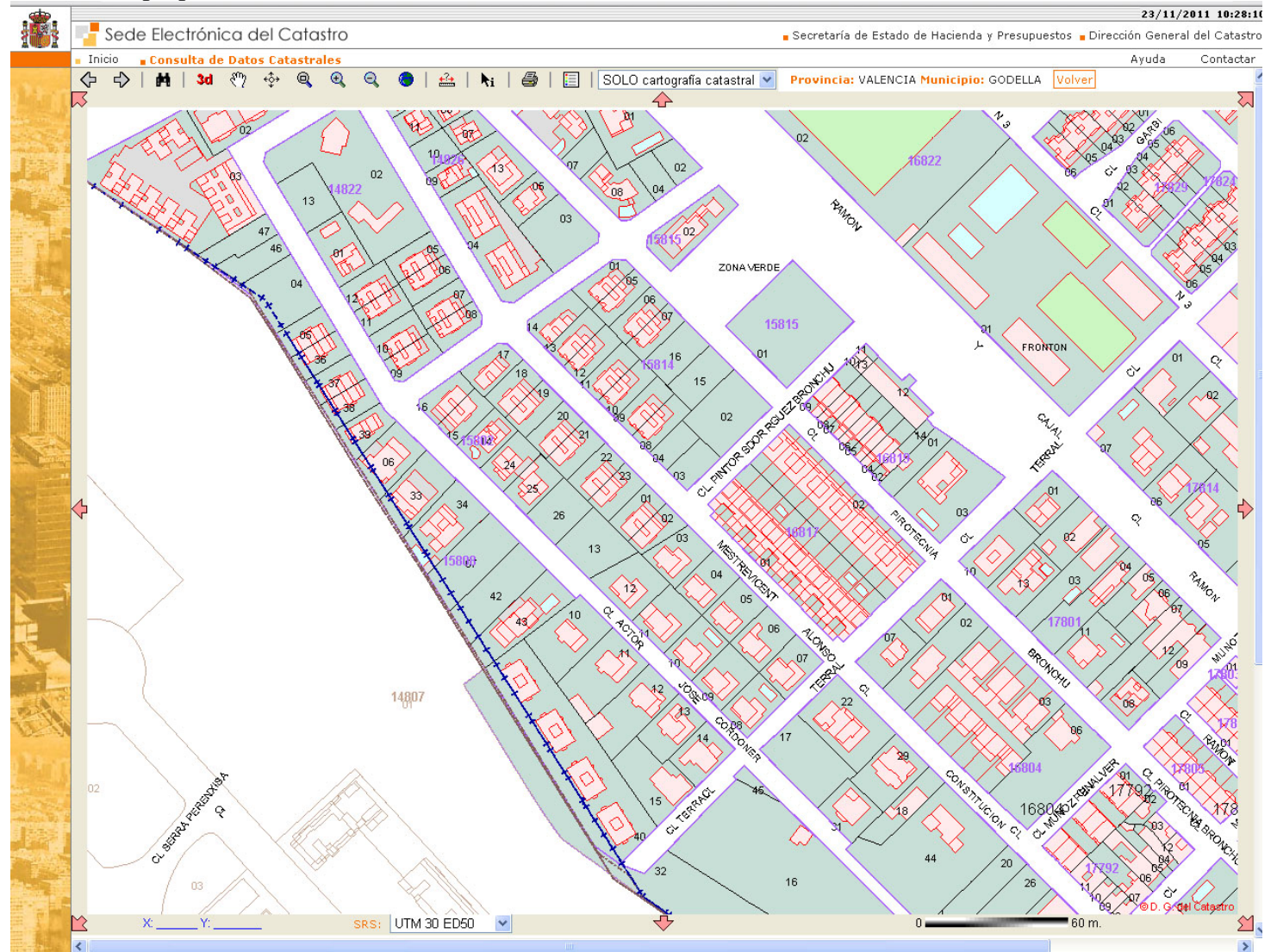

Figure 10. Cartography taken from the Spanish Cadastre's official web page showing the same boundary line as Fig.9. 


\section{METHODOLOGY}

As a result, a technical methodology to replace and georeference boundary lines has been extracted from the work carried out in the specified area. This precise, operative and economic methodology consists of:

- A thorough study of the geographical description of boundary lines and the geographical location of monuments

- Field inspection to locate monuments

- Precise and reliable georeferencing of existing monuments:

o Collecting data from geodetic vertex

o Collecting data from existing monuments

- Calculation of the coordinates of the disappeared monuments using field tablets from IGN

- Layout of calculated points and search for disappeared monuments

- If the monument is found: data record and georreferencing

- In case the monument has disappeared: placement of another monument with IGN field tablets

- Checking of results with cadastral cartography

\section{CONCLUSIONS}

The geodetic works required to define and map the boundaries of municipalities in Spain were carried out around one century ago. Due to the characteristics of the geodetic instruments, these works were not highly accurate. Combine with the fact that the lines defining the boundaries are not georeferenced, when there is a need to place the municipal boundaries in the official cartography, there are always difficulties.

It is very common, as in the case at hand, for there to be significant discrepancies between the cartography of every official agency and there is no real interest in solving this problem, so only when required by a private entity is the problem taken into account.

In the case that the council makes the effort to redefine the boundary line and add the resulting surface to the municipality, significant problems can arise, from taxation problems to supply problems.

\section{References}

1. Berné, J. L. et al, 2008, Catastro en España, Ed. UPV, Valencia.

2. Capdevila i Subirana, J., 2005, Treballs de la SCG, 60.

3. Collier, P., 2009, International Boundary Surveys and Demarcation in the late $19^{\text {th }}$ and early $20^{\text {th }}$ centuries, Survey Review, 41, (311): 2-13.

4. Dale, P. F., 2006, Reflections on the Cadastre, Survey Review, 38, (300): 491-498.

5. Demir, O., Uzun B. and Çete M., 2008. Turkish Cadastral System, Survey Review, 40, (307): 54-66.

6. Dirección General del Catastro. www.catastro.meh.es/esp/normativa1.asp?lu=m6\&im=m6i\#menu1_3.

[accessed Jun 23 2010].

7. Fábrega Golpe, J. et al., 2007, Proyecto que desarrolla de la Metodología para la optimización de la base de datos de líneas límite del Instituto Geográfico Nacional

8. National Geographical Institute of Spain (IGN) 
http://www.fomento.es/MFOM/LANG_CASTELLANO/DIRECCIONES_GENERAL ES/INSTITUTO_GEOGRAFICO/Geodesia/

[accessed October 19 2010].

9. Pirti A., Arslan N., Deveci B., Aydin O., Erkaya H. and Hosbas R.G., 2009, Real-

Time kinematic GPS for Cadastral Surveying, Survey Review, 41, (314): 339-351. 